\begin{tabular}{|c|c|c|}
\hline \hline & \begin{tabular}{c} 
International Journal of Current Research in \\
Biosciences and Plant Biology \\
\hline EXCELLENT \\
PUBLISHERS
\end{tabular} & Volume $4 \bullet$ Number 6 (June-2017) ・ ISSN: 2349-8080 (Online) \\
\hline
\end{tabular}

\title{
Pedological Characterization of Typical Soil of Dakawa Irrigation Scheme, Mvomero District, Morogoro Region, Tanzania
}

\author{
Halima R. Mbaga*, Balthazar M. Msanya and Jerome P. Mrema
}

Department of Soil and Geological Sciences, College of Agriculture, Sokoine University of Agriculture, P.O. Box 3008, Morogoro, Tanzania

*Corresponding author.

\begin{tabular}{|c|c|}
\hline Abstract & Article Info \\
\hline $\begin{array}{l}\text { This study was conducted to characterize dominant soil type at Dakawa Irrigation Scheme } \\
\text { (DIS), Tanzania. Typical soil at DIS was identified, excavated and described using FAO } \\
\text { (2006) Guidelines. Six disturbed samples were taken from soil profile horizons together } \\
\text { with three undisturbed core samples for laboratory analysis. The pedon developed from } \\
\text { Neogene alluvial parent materials under } \text { ustic moisture and isohyperthermic temperature } \\
\text { regimes. The pedon was very deep (> } 150 \mathrm{~cm}) \text {, moderately well drained, with gray to very } \\
\text { dark gray soil colours. CaCO } 3 \text { concretions characteristic of calcic horizon were observed } \\
\text { in subsoil. Soil texture was sandy clay loam throughout the pedon. pH was rated as } \\
\text { medium ( } 5.5-7.0) \text { to very high ( } 7.0-8.5) \text { respectively for topsoil and subsoil. OC and N } \\
\text { levels were very low; CEC and exchangeable bases were low to medium. Bulk densities } \\
\text { were high ( } 1.8 \text { gcm }{ }^{-3} \text { ) to very high }\left(>1.9 \text { gcm }{ }^{-3}\right) \text { for topsoil and subsoil, respectively. Study } \\
\text { on moisture retention properties showed that subsurface (95 - } 100 \text { cm) and intermediate } \\
\text { (45 - } 50 \text { cm) horizons retained more water than surface }(0-5 \text { cm) soil, congruent with } \\
\text { increasing clay content with depth. According to Soil Taxonomy and World Reference } \\
\text { Base for Soil Resources, pedon at DIS classified as Vertic Calciustepts and Haplic Vertic } \\
\text { Cambisols, respectively. These taxa reflect properties that may guide use and management } \\
\text { of soils at DIS including selection of crops and fertilizers and rates to use. Organic } \\
\text { fertilizers were recommended to increase organic matter content in soil. Use of acidifying } \\
\text { inorganic fertilizers and gypsum as soil amendments should also be taken onboard to } \\
\text { correct emerging sodicity. }\end{array}$ & $\begin{array}{l}\text { Accepted: } 17 \text { May } 2017 \\
\text { Available Online: } 06 \text { June } 2017 \\
\text { Key w o r d s } \\
\text { Chemical properties } \\
\text { Nutrient balance } \\
\text { Pedogenesis } \\
\text { Pedological characterization } \\
\text { Physical properties } \\
\text { Soil classification } \\
\text { Soil morphology }\end{array}$ \\
\hline
\end{tabular}

\section{Introduction}

Soil information gathered by systematic identification, grouping and delineation of different soils is required when sound interpretations towards land use potential are to be made (Msanya et al., 2003). There are several soil forming factors, which influence the morphology of a given soil. These including climate, parent material, biota, relief and time (Kalala et al., 2017). Plant nutrients in soils originate from parent materials from which soils were formed through the weathering of rocks and minerals (Agricultural Research Council, 2009). Plants obtain most of their nutrients and water from the soil through their root systems. Any factor that 
restricts root growth and activity has the potential to restrict nutrient availability even though the nutrients are available in the soil. These soil factors that can restrict ability of crop to absorb nutrients include soil compaction and soil moisture regime (Harvlin et al., 2005). Understanding these factors that cause nutrient deficiency in crops is important to avoid need for excessive fertilization beyond what is recommended (Harvlin et al., 2005). Thus, knowledge of physical and chemical properties of soils together with other ecological conditions of an area would aid in determining the correct types and amounts of fertilizers to be applied for optimum crop production and for enhancing improvement of soil fertility (Msanya et al., 2003). Soil fertility specialists need well characterized sites in order to carry out meaningful fertilizer trials (Kebeney et al., 2015). There is also a strong feeling that fertilizer trials should be conducted on well characterized soils to enhance transferability of information from one place to another (Msanya et al., 2003; Kebeney et al., 2015).

Pedological information is important to land users especially farmers who use the data to make decisions on what crops and management practices are best suited for the optimal and sustainable production of crops. According to Breimer et al. (1986), pedological studies provide a better understanding of spatial changes in the characteristics of the soil continuum so that soils may be used more efficiently for the benefit of mankind.

Although Tanzania has long history of collecting basic information on soil characterization in the form of soil surveys, this has only been concentrated in a few selected high potential areas (Kilasara et al., 1994).
Thus, the available information remains rather scanty relative to the large size of the country and its diverse soil and other land resources. The few existing soil resource inventories are characterized by their small scale nature with high level of generalization, being based on rather few observations scattered over large areas. A good data bank on soil properties and related site characteristics is inevitable for one to be able to advise both current and potential land users on how to use the land in the best possible way. Therefore, this study aimed at characterizing and classifying typical soils of Dakawa Irrigation Scheme (DIS) to provide the needed basic pedological information for proper decisions on land use and management of the soil resources.

\section{Materials and methods}

\section{Description of the study area}

The study was carried out at DIS in Mvomero District, Morogoro, Tanzania. The scheme covers an area of $2000 \mathrm{ha}$. It is located $45 \mathrm{~km}$ from Morogoro town, $7 \mathrm{~km}$ north east of Wami - Dakawa village and north - west of Wami River on an extensive flat plain. Some pertinent features of DIS are given in Table 1. Annual rainfall ranges between $580 \mathrm{~mm}$ and $1191 \mathrm{~mm}$. Rainfall distribution is bimodal with the short rains in October to January and the long rains in March to May (Fig. 1). The long rains ranging between $74 \mathrm{~mm}$ to $410 \mathrm{~mm}$ are the most reliable for crop production compared to the short rain $(50 \mathrm{~mm}$ to $387 \mathrm{~mm})$. The rainfall amount and distribution are inadequate particularly for rice production which is the main land use type in the area. The scheme uses Wami - Dakawa River as a source of water for irrigation.

Table 1. Important features of DIS, Mvomero District, Tanzania

\begin{tabular}{ll}
\hline Characteristics & Description \\
\hline Coordinates of the Centre of DIS & Latitude $6^{0} 24^{\prime} \mathrm{S}$ and Longitude $37^{0} 33^{\prime} \mathrm{E}$. \\
Altitude (m asl) & 361 \\
Landform & Alluvial plain, Almost flat, slope $<1 \%$, \\
Lithology & Alluvium derived from Neogene parent material originating from Mnguu \\
& Mountains (Msanya et al., 2003) \\
Mean Annual Rainfall (mm) & 985 \\
Ranfall Distribution Pattern & Bimodal with short rains lasting from October - January, long rains from March - \\
& May \\
Land use & Paddy rice cultivation under basin irrigation system \\
Soil Temperature Regime (STR) & Isohyperthermic \\
Soil Moisture Regime (SMR) & Ustic \\
\hline
\end{tabular}

Seasonal variations in temperature at Dakawa are minimal with an average monthly maximum ranging between $22^{\circ} \mathrm{C}$ in February to $32^{\circ} \mathrm{C}$ in July and mean monthly minimum temperature ranges from $15^{\circ} \mathrm{C}$ to 
$22^{\circ} \mathrm{C}$ for February and July, respectively (Fig. 2). The physiography of the area is characteristically Mbuga flat (part of Wami flats). According to land suitability evaluation and soil characterization by Msanya et al. (2003), the soils of the area are of mixed clay mineralogy comprising kaolinite, illite and smectite.

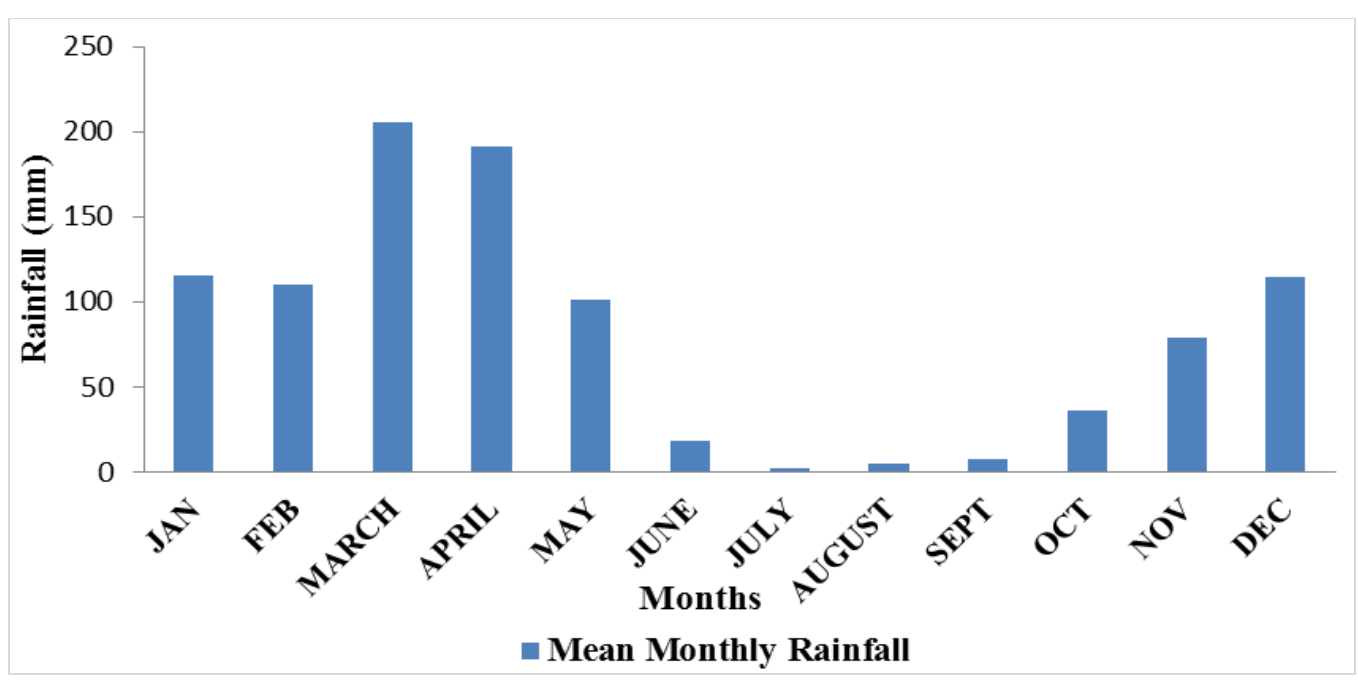

Fig. 1: Mean monthly rainfall at Dakawa Irrigation Scheme, Morogoro, Tanzania (2004-2014).

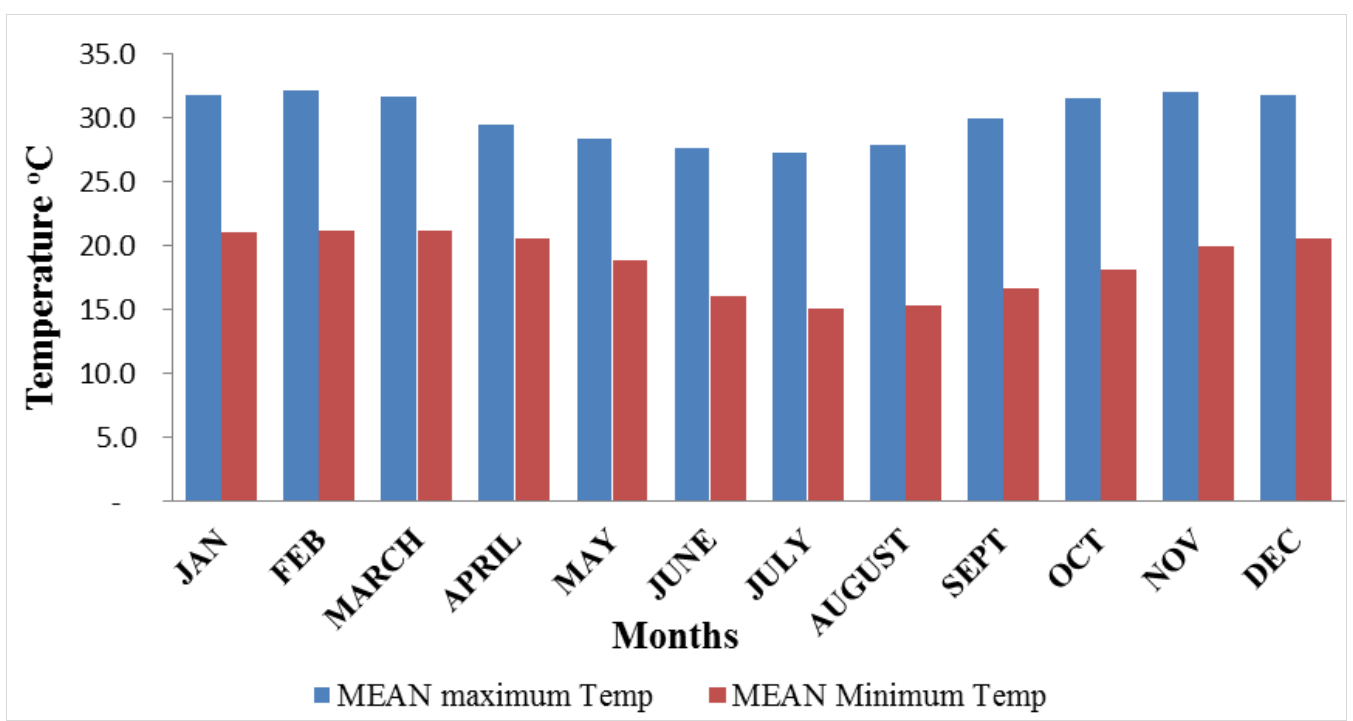

Fig. 2: Mean monthly maximum and minimum temperatures at Dakawa Irrigation Scheme, Morogoro, Tanzania (2005-2014).

Dakawa Irrigation Scheme is located within the Lowland Agro-ecological Zone (river valley and basin) [Ministry of Agriculture, Food and Cooperatives (MAFC) (2014)]. This zone is comprised of Mgeta, Kafa, Ruvu, Wami, Msongozi, Mbulumi and Ngerengere river valleys in Morogoro and Mvomero Districts; Wami-Mkata plains and Mkondoa valley in Kilosa District and Luhombero Plains in Ulanga District (MAFC, 2014). The zone is densely populated in the upper parts of the valleys, and sparsely populated in the inner parts of the valleys due to occurrence of floods during the rainy season. The inner parts of the valleys are commonly used for rice cultivation.

\section{Field survey and characterization}

Reconnaissance field survey was carried out based on transect walks, auger observations and profile descriptions to establish soil patterns on the basis of landforms and other physiographic attributes (FAO, 2006). Data on landforms, soil morphological characteristics, elevation, slope gradient, parent material 
(lithology), vegetation and land use/crops were collected from different observation sites that represented major landforms and soils identified during reconnaissance survey. Data were then entered on special field description forms designed according to the FAO Guidelines for Soil Description (FAO, 2006). Based on information gathered during reconnaissance survey, soil variability was established to be minimal, thereby justifying the opening of a single profile for characterization of the soil as representative of the study area. A soil profile of $2.5 \mathrm{~m}$ by $1.5 \mathrm{~m}$ was excavated to the depth of $2 \mathrm{~m}$. Soil horizons were identified, demarcated, described and sampled according to FAO Guidelines for Soil Description (FAO, 2006).

Disturbed $1 \mathrm{~kg}$ samples were taken from each genetic soil horizon for laboratory analysis of physical and chemical properties. Three undisturbed samples were also taken from the profile for determination of bulk density and soil moisture retention properties.

\section{Laboratory soil analysis}

Undisturbed soil samples were used to determine bulk density and soil moisture retention characteristics as follows: bulk density by core method (Black and Hartge, 1986) using $100 \mathrm{cc}$ cores; soil moisture retention properties by using sand-kaolin box for low suction values (Klute, 1986) and by pressure plate apparatus for high suction values (National Soil Service (NSS), (1990)). Disturbed soil samples were used for other physical properties, and chemical properties. Particle size analysis was done by Gee and Bauder (1986) method and textural classes determined by USDA (1975) textural triangle.

Soil $\mathrm{pH}$ was measured potentiometrically in water and 1 $\mathrm{M} \mathrm{KCl}$ at a ratio of 1:2:5 soil-water and soil- $\mathrm{KCl}$ suspensions (McLean, 1986). Organic carbon was determined by wet oxidation method (Nelson and Sommers, 1982) and organic carbon converted to organic matter by multiplying by a factor of 1.724 (Duursma and Dawson, 1981). Total nitrogen was determined by micro-Kjeldahl digestion - distillation method (Bremner and Mulvaney, 1982). Available P was determined by Olsen method (Shio, 1996). Cation exchange capacity (CEC) was determined by neutral buffered 1M ammonium acetate saturation method (Sumner and Miller, 1996). $\mathrm{Ca}^{2+}, \mathrm{Mg}^{2+}, \mathrm{K}^{+}$and $\mathrm{Na}^{+}$in ammonium acetate filtrates were measured by Atomic Absorption Spectrophotometer. Total exchangeable bases (TEB) were calculated as sum of exchangeable bases $\left(\mathrm{Ca}^{2+}, \mathrm{Mg}^{2+}, \mathrm{Na}^{+}\right.$and $\left.\mathrm{K}^{+}\right)$. Formulae used for calculation of base saturation and exchangeable sodium percent (ESP) are derived from Landon (1991). Plant extractable $\mathrm{Cu}, \mathrm{Zn}, \mathrm{Fe}$ and $\mathrm{Mn}$ were extracted by DTPA method (Lindsay and Norvell, 1978). Electrical conductivity was determined in 1:2:5 soil:water suspensions, electrometrically using electric conductivity meter (Rhoades, 1996).

\section{Soil classification}

Using field and laboratory data, the soil was classified to family level of USDA Soil Taxonomy (Soil Survey Staff, 2014) and to tier-2 of FAO World Reference Base for Soil Resources (IUSS Working Group WRB, 2015).

\section{Results and discussion}

\section{Soil morphology}

Some key morphological properties of the soil profile at DIS are presented in Table 2. The profile was very deep (> $150 \mathrm{~cm}$ ), moderately well drained, with gray to very dark gray soil colour. Structure of the upper three horizons was moderate, medium and coarse subangular blocky, whereas soil consistence was very hard when dry, firm to friable when moist, sticky and plastic when wet. The subsoil $(61-175+\mathrm{cm})$ structure was weak, fine and medium subangular blocky whereas consistence was friable when moist, sticky and plastic when wet. Presence of $\mathrm{CaCO}_{3}$ concretions was common in the subsoil (61$175+\mathrm{cm}$ ). Roots were distributed throughout the profile although abundance was decreasing with increasing depth. Soil horizon boundaries were quite distinct, ranging mostly from clear to abrupt with either smooth or wavy horizon topography.

\section{Physical properties}

Some physical properties of the studied soil profile are presented in Table 3. Clay content increased while sand content decreased with soil depth. Silt contents were generally very low throughout the profile and did not show any clear trend with depth. Higher sand contents in topsoils as compared to subsoils might be due to migration of finer soil particles in suspension from topsoils down the profile. Another reason for higher sand content in topsoil may be due to surface runoff which washed away finer soil particles thereby leaving behind large amounts of sand particles. On the overall, 
soil texture was sandy clay loam (SCL) throughout the profile. Soil texture is the most stable physical characteristic which influences several other soil properties like soil structure, consistence, soil moisture regime and infiltration rate, runoff rate, erodibility, workability, permeability, root penetrability and fertility status of soil (Landon, 1991). Based on the textural class, the soil at DIS has good water and nutrient retention capacities, hence suitable for rice crop commonly grown in the study area.

Table 2. Key morphological characteristics of studied pedon at DIS, Mvomero District, Tanzania.

\begin{tabular}{|c|c|c|c|c|c|c|c|}
\hline Horizon & Depth $(\mathrm{cm})$ & $\begin{array}{l}\text { Textural } \\
\text { class }\end{array}$ & Colour (moist) & Consistence & Structure & $\begin{array}{l}\mathrm{CaCO}_{3} \\
\text { concretions }\end{array}$ & $\begin{array}{l}\text { Horizon } \\
\text { boundary }\end{array}$ \\
\hline Ap & $0-11$ & SCL & vdg (10YR3/1) & vh,fr,s\&p & $\mathrm{m} \mathrm{m \& c}, \mathrm{sbk}$ & - & cs \\
\hline BAw1 & $11-39$ & SCL & $\operatorname{vdg} \quad(10 Y R 3 / 1)$ & $v h, f r, s \& p$ & $\mathrm{~m}$ m\&c, sbk & - & cs \\
\hline BCk & $61-97 / 110$ & SCL & dg (10YR4/1) & fr, s\&p & w f\&m, sbk & $\sqrt{ }$ & $\mathrm{cw}$ \\
\hline Ck1 & $97 / 110-130$ & SCL & $\operatorname{lbg}(10 \mathrm{YR} 6 / 2)$ & fr, s\&p & w f\&m,sbk & $\sqrt{ }$ & as \\
\hline Ck2 & $130-175+$ & SCL & $\mathrm{g}(10 \mathrm{YR} 6 / 1)$ & fr, s\&p & w f\&m, sbk & $\sqrt{ }$ & NA \\
\hline
\end{tabular}

DIS = Dakawa Irrigation Scheme SCL= sandy clay loam; fr = friable; $s=$ sticky; $p=$ plastic, $v$ h = very hard, $h=$ hard, $v d g=$ very dark gray, $\mathrm{dg}=$ dark gray, $\mathrm{lbg}=$ light brownish gray, $\mathrm{g}=$ gray, $\mathrm{m}$ m\&c sbk = moderate, medium and coarse, subangular blocky; $\mathrm{w}$ f\&m, sbk = weak fine and medium subangular blocky, $\mathrm{a}=\mathrm{abrupt} ; \mathrm{c}=\mathrm{clear} ; \mathrm{s}=\mathrm{smooth} ; \mathrm{w}=\mathrm{wavy}$. NA= Not applicable; $\sqrt{ }=$ presence of $\mathrm{CaCO}_{3}$ concretions giving strong effervescence with dil. $\mathrm{HCl} ; \mathrm{NA}=\mathrm{Not}$ applicable.

Table 3. Physical properties of studied pedon at DIS, Mvomero District, Tanzania.

\begin{tabular}{lllllll}
\hline Horizon & Ap & BAw1 & BAw2 & BCk & Ck1 & Ck2 \\
\hline Soil depth (cm) & $0-11$ & $11-39$ & $39-61$ & $61-97 / 110$ & $97 / 110-130$ & $130-175$ \\
Clay \% & 24 & 26 & 30 & 32 & 32 & 32 \\
Silt \% & 4 & 4 & 2 & 2 & 4 & 6 \\
Sand \% & 72 & 70 & 68 & 66 & 64 & 62 \\
Textural class & SCL & SCL & SCL & SCL & SCL & SCL \\
Bulk density & 1.81 & NA & 1.93 & NA & 1.92 & NA \\
\hline
\end{tabular}

$\mathrm{SCL}=$ Sand clay loam, NA= Not Applicable.

Bulk density (BD) values of the studied soil horizons are presented in Table 3. BD values of the three horizons (topsoil, intermediate and subsoil) were $>1.8 \mathrm{gcm}^{-3}$. High bulk densities $>1.75 \mathrm{gcm}^{-3}$ for sands or 1.46 to $1.63 \mathrm{gcm}^{-3}$ for silts and clays, may impose many stresses such as mechanical resistance, poor aeration and changes in hydrological system in soil such as poor infiltration of water (Landon, 1991). Topsoil BD was slightly lower than values in the intermediate and subsoil horizons. This observation was attributed to relatively higher organic carbon content hence organic matter in topsoil (Dalal and Mayer, 1986). The generally high BD values observed in the soil profile were largely attributed to use of heavy machines in tillage, harvesting and hauling operations. This condition although unfavourable for many crops, it is favourable in the case of paddy rice cultivation as it encourages water ponding in the field.

Moisture retention characteristic curves of the studied soil are presented in Figure 3. The curves show that subsurface $(95-100 \mathrm{~cm})$ and intermediate horizons (45 $50 \mathrm{~cm})$ retained more water than surface $(0-5 \mathrm{~cm})$ soil under all suction pressures. The trend of moisture retained at various suction pressures was as follows: subsurface soil $>$ intermediate $>$ soil surface soil. This is in line with the fact that clay content increased with depth (Table 3). Similar trend was observed for other soils in Tanzania by Massawe et al. (2017). When clay content increases, ability of soil to retain water increases at any particular matric potential and the more gradual is the slope of the curves (Hillel, 2007).

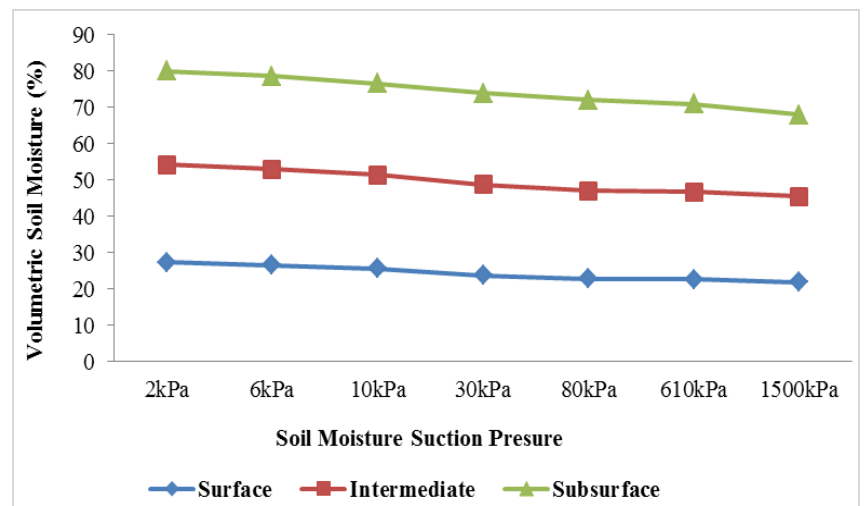

Fig. 3: Soil moisture characteristic curves of the studied pedon at Dakawa Irrigation Scheme Morogoro, Tanzania. 


\section{Chemical properties}

Some chemical properties of the studied soil profile are presented in Table 4 and Table 5. Soil $\mathrm{pH}$ increased with profile depth (Table 4). The lowest soil $\mathrm{pH}$ (in water) was observed in topsoil (Ap horizon) and the highest value in subsoils in the $\mathrm{BCk}$ and $\mathrm{Ck} 1$ horizons. Landon (1991) rated these $\mathrm{pH}$ values as medium (5.5 - 7.0) to very high (7.0 - 8.5) for topsoil and subsoil, respectively. High soil $\mathrm{pH}$ of this soil could be attributed to relatively high concentrations of $\mathrm{Na}, \mathrm{Ca}$ and $\mathrm{Mg}$ ions which were also increasing with soil depth. The $\mathrm{Na}$ might be originating from surface evaporation of water in Wami River containing substantial amount of $\mathrm{Na}$ due to alluvial deposition (Kisetu et al., 2013).

$\mathrm{Ca}$ and $\mathrm{Mg}$ might be originating from the underlying bedrock. Generally, soil horizons, showed positive delta $\mathrm{pH}\left(\mathrm{pH}_{\text {water }}-\mathrm{pH}_{\mathrm{KCl}}\right)$ values, which indicate that the exchange sites of the soil colloidal fractions, were mostly negatively charged (Bohn et al., 1985), hence implying high ability to hold cations.

Organic carbon (OC) contents ranged from $0.24 \%$ in subsoil to $1.01 \%$ in topsoil (Table 4). According to Landon (1991) these values are rated as very low since they are $<2 \%$. The trend shows that OC decreased with depth. OC in the topsoil was higher than in the other horizons probably because of accumulation of plant root materials and other organic residues in topsoil. The generally low OC content in the study pedon could be attributed to levelling process which led to removal of soil layers rich in OC during construction of irrigation infrastructure.

Total nitrogen (TN) contents in the soil ranged from 0.01 in subsoil to $0.07 \%$ in topsoil (Table 4). According to Landon (1984) these values were rated as very low. TN levels showed clear decreasing trend with soil depth indicating that most of the $\mathrm{N}$ in the soil was contained in soil organic matter.

$\mathrm{C} / \mathrm{N}$ ratios ranged from $13-24$ and there was a general trend of widening of the ratios with increasing depth. According to Msanya et al. (2001), the C/N ratios in the upper $100 \mathrm{~cm}$ were rated to be of moderate to good quality whereas those in the deeper subsoil were rated to be of poor quality.

Available phosphorus in DIS soil decreased with soil depth (Table 4). According to Landon (1991), Olsen phosphorus values of $<7 \mathrm{mg} \mathrm{P} \mathrm{kg}^{-1}$ soil are rated as low, 7 to $20 \mathrm{mg} \mathrm{P} \mathrm{kg}^{-1}$ soil as medium and $>20 \mathrm{mg} \mathrm{Pkg}^{-1}$ soil as high. Since $\mathrm{P}$ values obtained in all six horizons of the profile were $>20 \mathrm{mg} \mathrm{P} \mathrm{kg}^{-1}$, then available $\mathrm{P}$ of the studied soil would be categorized as high. High Olsen available $\mathrm{P}$ may be largely attributed to high $\mathrm{P}$ content in the soil's parent material and to some extent to continuous application of $\mathrm{P}$ fertilizers during rice cultivation in the study area.

Table 4. Selected chemical properties of studied pedon at DIS, Mvomero District, Tanzania.

\begin{tabular}{llllllll}
\hline \multirow{2}{*}{ Horizons } & \multirow{2}{*}{ Depth $(\mathbf{c m})$} & $\mathbf{p H ~ 1 : 2 : 5}$ & & $\mathbf{O C}$ & $\mathbf{T N}$ & \multirow{2}{*}{ C/N } & \multicolumn{2}{c}{\begin{tabular}{l} 
Avail. P Olsen \\
\cline { 3 - 6 }
\end{tabular}} & $\mathbf{\mathbf { H } _ { 2 } \mathbf { O }}$ & $\mathbf{K C l}$ & $\mathbf{\%}$ & $\mathbf{\%}$ & & $\mathbf{m g k g}^{-\mathbf{1}}$ \\
\hline Ap & $0-11$ & 6.59 & 4.75 & 1.01 & 0.07 & 14 & 56.50 \\
BAw1 & $11-39$ & 7.72 & 5.73 & 0.48 & 0.03 & 16 & 56.05 \\
BAw2 & $39-61$ & 8.68 & 7.05 & 0.32 & 0.02 & 16 & 55.16 \\
BCk & $61-97 / 110$ & 8.82 & 7.24 & 0.27 & 0.02 & 13 & 54.71 \\
Ck1 & $97 / 110-130$ & 8.82 & 7.35 & 0.24 & 0.01 & 24 & 54.56 \\
Ck2 & $130-175+$ & 7.26 & 7.36 & 0.24 & 0.01 & 24 & 53.21 \\
\hline
\end{tabular}

CEC of the studied profile ranged from $17.52 \mathrm{cmol}_{\mathrm{d}} / \mathrm{kg}$ for topsoil and 10.76 to $21.60 \mathrm{cmol}_{\mathrm{C}} / \mathrm{kg}$ soil for subsoil, respectively (Table 5). Landon (1984) rated these values as medium for topsoil and low to medium for subsoil. There was no clear trend of increase or decrease in CEC with soil depth. Low to medium CEC of soil could be attributed to low organic matter content of soil as well as nature of parent materials from which the soil developed, and type of clay minerals dominant in the soil. Koelling (1995) reported that organic matter and clay minerals in soils have negatively charged sites on their surfaces which adsorb and hold positively charged ions (cations) by electrostatic force. The electrical charge is critical to the retention and supply of nutrients to plants because many nutrients exist as cations dissolved in soil solution and adsorbed on surfaces of soil colloids. CEC might be viewed as reservoir of plant nutrients, and the higher the CEC, the larger the reservoir (Koelling, 1995). 
Values of exchangeable bases $(\mathrm{Ca}, \mathrm{Mg}, \mathrm{K}$ and $\mathrm{Na}$ ) are presented in Table 5. Exchangeable Ca levels increased with soil depth. According to Msanya et al. (2001), these values were rated as low $\left(0.5-2.0 \mathrm{cmol}_{\mathrm{c}} / \mathrm{kg}\right)$ to medium/high $\left(2.1-6.0 \mathrm{cmol}_{\mathrm{c}} / \mathrm{kg}\right)$ respectively in topsoil and subsoil. Increase of exchangeable $\mathrm{Ca}$ levels with depth was attributed to presence of $\mathrm{CaCO}_{3}$ concretions which also increased with depth. Exchangeable $\mathrm{Mg}$ in the profile increased with depth and ranged from 2.27 $\mathrm{cmol}_{\mathrm{c}} / \mathrm{kg}$ (high) for topsoil to $>4.1 \mathrm{cmol}_{\mathrm{C}} / \mathrm{kg}$ (very high) in subsoil. High values of exchangeable $\mathrm{Mg}$ in the profile could be attributed to high $\mathrm{Mg}$ content in the soil's parent material.

Exchangeable $\mathrm{K}$ values (Table 5) show a general trend of decreasing down the profile. According to Landon (1991), these values were rated as very low $(<0.1$ $\mathrm{cmol}_{\mathrm{c}} / \mathrm{kg}$ in subsoil and as medium $\left(0.3-0.6 \mathrm{cmol}_{\mathrm{c}} / \mathrm{kg}\right.$ in topsoil.

Exchangeable $\mathrm{Na}$ ranged from $0.3 \mathrm{cmol}_{\mathrm{c}} / \mathrm{kg}$ to 4.85 $\mathrm{cmol}_{\mathrm{c}} / \mathrm{kg}$ in topsoil and subsoil, respectively. Landon (1991) rated these values as low $\left(0.10-0.30 \mathrm{cmol}_{\mathrm{c}} / \mathrm{kg}\right)$ and very high ( $>2 \mathrm{cmol}_{\mathrm{c}} / \mathrm{kg}$ ), respectively in topsoil and subsoil. The trend showed that exchangeable $\mathrm{Na}$ increased with soil depth. Low levels of exchangeable $\mathrm{Na}$ in topsoil may be attributed to its solubility and mobility when soils are sufficiently moist which leads to leaching of $\mathrm{Na}$ from topsoil and subsequent accumulation in subsoil (Zonn, 1986). Exchangeable sodium percent (ESP) values are presented in Table 5. There was a general trend of ESP increasing with soil depth. According to Msanya et al. (2001), ESP values in topsoil were rated as low (non-sodic) $(<6.0 \%)$ in topsoil and strongly sodic to very strongly sodic (16.0 -
$>26.0 \%)$ in the major part of the subsoil. The ESP values imply that there is an apparent sodicity problem developing in the studied soil and serious attention must be taken into consideration to arrest/minimize the problem for example by considering possibility of gypsum application and / or drainage.

Base saturation of the studied soil varied from horizon to horizon. The lowest value was $25 \%$ for the topsoil (horizon Ap) and maximum value of $128 \%$ for subsoil (horizon BAw2) (Table 5) indicating presence of soluble salts. Low base saturation in the topsoil is an indication of intensive leaching of bases down the soil profile.

The electric conductivity of the studied soil is as presented in Table 5. The trend shows that the EC increased with soil depth probably due to increase in $\mathrm{Na}$ levels. The lowest value of EC was $0.08 \mathrm{dS} / \mathrm{m}$ and the highest value was $2.21 \mathrm{dS} / \mathrm{m}$ for topsoil and subsoil, respectively. Except for the bottom horizon, all other horizon values were $<1.7 \mathrm{dS} / \mathrm{m}$ indicating that the Ec of the studied soil has no effect on crop yield reduction (Landon, 1991).

\section{Nutrient balance}

The availability of nutrients for plant uptake does not depend only on their absolute levels in soils but also depends on nutrient balance. Thus, availability of cations to plants is sometimes influenced by several ratios including $\mathrm{Ca}: \mathrm{Mg}, \mathrm{Mg}: \mathrm{K}$ and $\mathrm{K}: \mathrm{TEB}$ (where TEB is total exchangeable bases) (Msanya et al., 2016). The nutrient ratios for the studied soil profile at DIS are presented in Table 6.

Table 6. Soil nutrient balance for soil pedon at DIS in Mvomero District, Morogoro Region, Tanzania

\begin{tabular}{llllll}
\hline Horizon & Depth $(\mathbf{c m})$ & $\mathbf{C a} / \mathbf{M g}$ & $\mathbf{M g} / \mathbf{K}$ & $\mathbf{C a} / \mathbf{T E B}$ & \%(K/TEB) \\
\hline Ap & $0-11$ & 0.62 & 6.14 & 0.32 & 8.55 \\
BAw1 & $11-39$ & 0.41 & 30.83 & 0.24 & 1.95 \\
BAw2 & $39-61$ & 0.69 & 63.00 & 0.50 & 0.80 \\
BCk & $61-97 / 110$ & 0.56 & 77.78 & 0.28 & 0.66 \\
Ck1 & $97 / 110-130$ & 0.62 & 78.13 & 0.27 & 0.56 \\
Ck2 & $130-175+$ & 0.69 & 102.75 & 0.30 & 0.42 \\
\hline
\end{tabular}

$\mathrm{Ca} / \mathrm{Mg}$ ratios ranged from 0.41 to 0.69 . According to Msanya et al. (2001), $\mathrm{Ca} / \mathrm{Mg}$ ratio ranges of 2 to 4 are considered favourable for most crops. Based on this rating, the observed $\mathrm{Ca} / \mathrm{Mg}$ ratios were below the optimum range, hence can limit uptake of $\mathrm{Mg}$ by plants. $\mathrm{Mg} / \mathrm{K}$ ratios ranged from 6.14 to 102.75 . Landon (1991) categorized $\mathrm{Mg} / \mathrm{K}$ ratios of 1 to 4 as optimal for nutrient uptake by plants. Therefore the observed ratios were above the optimum range which implies that $\mathrm{Mg}$ was very high and can lead to nutrient imbalance and toxicity. $\mathrm{Ca} / \mathrm{TEB}$ ratios ranged from 0.25 to 0.5 . According to Landon (1991), Ca/TEB ratios of $<0.5$ are 
considered favourable for uptake of other cations, particularly $\mathrm{Mg}$ and/or K. Percent (K/TEB) ranged from 0.42 to 8.55 and decreased down the profile (Table 6). \% (K/TEB) for topsoil was above $2 \%$ which is considered favourable for most tropical crops (Uwingabire et al., 2016; Uwitonze et al., 2016).

\section{Pedogenesis}

Among noticeable pedogenic processes in the studied soil include calcification (accumulation of $\mathrm{CaCO} 3$ ) in the subsoil, leaching (washing out of soluble salts) from the solum, salinization (accumulation of soluble salts) in the subsoil and alkalization (solonization) (accumulation of $\mathrm{Na}$ ions on the exchange sites) in the subsoil. Pedogenesis has also been affected to some degree by anthropogenic activities notably through leveling for irrigation and compaction by heavy machinery during various field operations.

\section{Soil classification}

Soil morphological and laboratory analytical data presented in Tables 1, 2, 3, 4 and 5 were used to define the diagnostic horizons and other features used for the classification of soil at DIS. Table 7 presents the diagnostic horizons and features for classifying the soils to family level according to USDA Soil Taxonomy (Soil Survey Staff, 2014). At the first level (order) of the USDA Soil Taxonomy the soils have been classified as Inceptisols. Similarly, Table 8 presents a summary of the diagnostic properties of the soil profile and identifies the prefix and suffix qualifiers, which allowed the classification of the soil up to the TIER-2 of the FAO World Reference Base Classification Scheme (IUSS Working Group WRB, 2015). According to WRB for Soil Resources the soils of the study area were classified as Cambisols at the Reference Soil Group level (TIER-1).

Table 7. Summary of diagnostic horizons, other features and classification of soil pedon at DIS, Mvomero District, Tanzania (USDA Soil Taxonomy- Soil Survey Staff, 2014)

\begin{tabular}{|c|c|c|c|c|c|c|}
\hline \multirow{2}{*}{$\begin{array}{l}\text { Diagnostic } \\
\text { epipedon and } \\
\text { subsurface } \\
\text { horizon } \\
\end{array}$} & \multirow[b]{2}{*}{ Other diagnostic features } & \multicolumn{5}{|c|}{ Soil Taxonomy Taxa } \\
\hline & & Order & Suborder & Great group & Subgroup & Family \\
\hline $\begin{array}{l}\text { Ochric epipedon; } \\
\text { cambic B horizon; } \\
\text { calcic horizon }\end{array}$ & $\begin{array}{l}\text { Ustic SMR, Isohyperthermic STR, } \\
\text { Slope } 0 \text {-1\% - almost flat; loamy } \\
\text { (sand clay loam particle size } \\
\text { distribution); calcareous; very deep; } \\
\text { presence of wide deep cracks, }\end{array}$ & Inceptisols & Ustepts & Calciustepts & $\begin{array}{l}\text { Vertic } \\
\text { Calciustepts }\end{array}$ & $\begin{array}{l}\text { Almost flat, very deep, } \\
\text { loamy (sand clay } \\
\text { loam), calcareous, } \\
\text { ustic, isohyperthemic } \\
\text { Vertic Calciustepts }\end{array}$ \\
\hline
\end{tabular}

Table 8. Diagnostic horizons, other features and WRB soil names for soil pedon at DIS, Mvomero District, Tanzania (IUSS Working Group WRB, 2015).

\begin{tabular}{|c|c|c|c|c|c|}
\hline $\begin{array}{l}\text { Diagnostic } \\
\text { horizon }\end{array}$ & $\begin{array}{l}\text { Other diagnostic } \\
\text { features/ materials }\end{array}$ & $\begin{array}{l}\text { Reference soil } \\
\text { group (RSG) }\end{array}$ & $\begin{array}{l}\text { Principal } \\
\text { qualifiers }\end{array}$ & $\begin{array}{l}\text { Supplementary } \\
\text { qualifiers }\end{array}$ & WRB soil name \\
\hline $\begin{array}{l}\text { Cambic } \\
\text { horizon, } \\
\text { Calcic } \\
\text { horizon }\end{array}$ & $\begin{array}{l}\text { Vertic characteristics; } \\
\text { very hard } \\
\text { consistence; } \\
\text { Calcareous. }\end{array}$ & Cambisols & $\begin{array}{l}\text { Vertic, } \\
\text { Haplic }\end{array}$ & $\begin{array}{l}\text { Calcaric, } \\
\text { Endoeutric, } \\
\text { Greyic }\end{array}$ & $\begin{array}{l}\text { Haplic Vertic Cambisols } \\
\text { (Calcaric, Endoutric, Greyic) }\end{array}$ \\
\hline
\end{tabular}

\section{Conclusions and recommendations}

The studied pedon classified as Vertic Calciustepts and Haplic Vertic Cambisols respectively in USDA Soil Taxonomy and World Reference Base for Soil Resources Systems of Soil Classification. Typically the pedon is very deep, moderately well drained with gray to very dark gray colour and had sand clay loam texture throughout its profile depth. The soil has high $\mathrm{pH}$ and low TN, CEC and SOM. Generally the fertility status of the soil was categorized as marginal to moderate particularly for paddy rice which is the major crop produced in Dakawa Irrigation Scheme. It is inevitable to use organic manure and acidic fertilizers such as ammonium sulphate to enhance availability of deficient plant nutrients. The soil showed indicators of sodicity which require immediate solution through careful application of gypsum and drainage.

\section{Conflict of interest statement}

Authors declare that they have no conflict of interest. 


\section{Acknowledgement}

The authors greatly appreciate the assistance received from the Alliance for Green Revolution in Africa (AGRA) through its Soil Health Project (Number 2013SHP009) for financing the research.

\section{References}

Agricultural Research Council (ARC), 2009. Republic of South Africa. Department of Education, Soil science course material. Agroecosyst. 53, 83-92.

Black, G.R. and Hartge, K.H., 1986. Bulk Density. In: Methods of Soil Analysis. Part 1. Agronomy Monograph No. 9. (Edited by Klute, A.). American Society of Agronomy and Soil Science Society of America, Madison, Wisconsin. Pp.364-376.

Bohn, H.J., McNeal, B.L. and O'Connor, G.A., 1985. Soil Chemistry. Wiley Interscience Publication. New York. 341p.

Breimer, R.F.,van Kekem, A.J. and Reuler, H., 1986. Guidelines for Soil Survey and Land Evaluation. In Ecological Research, UNESCO. Paris and New York. pp. 124.

Bremner, J.M. and Mulvaney, C.S., 1982. Total nitrogen. In: Methods of Soil Analysis. Part 2. Agronomy Monograph no. 9. (Edited by Page, L.A., Miller, R.H. and Keeney, D.R.).(Second Edition) American Society of Agronomy, Madison, Wisconsin. pp.595-624.

Dalal, R. and Meyer, R.J., 1986. Long term trend in fertility of soils under continuous cultivation and cereal cropping in Queensland II. Total organic carbon and its rate of loss from soil profile. Aust. J. Soil Res. 24, 301-309.

Duursma, E.K. and Dawson, R., 1981. Marine organic chemistry: Evolution, Composition, Interactions and Chemistry of Organic Matter. In: Seawater. Elsevier, Amsterdam. 521p.

FAO, 2006. Guidelines for Soil Description. Food and Agriculture Organization of the United Nations, Rome. 97p.

Gee, G.W. and Bauder, J.W., 1986. Particle size analysis. In: Methods of Soil Analysis, Part 1. Physical and Mineralogical Methods. Agronomy series No 9. (Edited by Klute, A). American Society of Agronomy Madison Wisconsin, USA. pp.383409.

Harvlin J.L., Beaton, J.D., Tisdale, S.L and Nelson, W.L., 2005. Soil Fertility and Fertilizers. (7th Edition) Upper Saddle River, New Jersey. 515p.
Hillel, D., 2007. Soil in the Environment: Crucible of Terrestrial Life. $1^{\text {st }}$ Edn. Academic Press/Elsevier, Amsterdam. ISBN: 9780123485366. 320p.

IUSS Working Group WRB, 2015. World Reference Base for Soil Resources 2014, update 2015. International Soil Classification System for Naming Soils and Creating Legends for Soil Maps. World Soil Resources Reports No. 106. FAO, Rome.

Kalala A. M., Msanya, B. M., Semoka, J. M., Amuri. N. A., 2017. Pedological characterization of some typical alluvial soils of Kilombero District, Tanzania. Am. J. Agric. For. 5(1), 1-11.

Kebeney, S.J., Msanya, B.M., Ng'etich, W.K., Semoka, J.M.R., Serrem, C.K., $2014 . \quad$ Pedological characterization of some typical soils of Busia County, Western Kenya: Soil morphology, physicochemical properties, classification and fertility trends. Int. J. Plant Soil Sci. 4(1), 30-44.

Kilasara, M., Magoggo, J.P., Msanya, B.M., 1994. Land resource management in Tanzania. In: Towards Developing a Programme Research for the Faculty of Agriculture to the Year 2000 (Eds.: Tarimo, A.J.P., Rutatora, D.F., Mattee, A.Z.). Proceedings of the Faculty of Agriculture Research Workshop held at the Institute of Continuing Education, Sokoine University of Agriculture, Tanzania 21st - 23rd March 1993, Morogoro, Tanzania.

Kisetu, E., Kasian, J. and Mtakimwa, Z.S., 2013. Determination of urea-N levels application to Nerica -4 cultivar of rice (Oryza sativa L.) grown on soils of Dakawa Morogoro, Tanzania. Int. J. Agric. Sci. $1(6), 73-80$.

Klute, A., 1986. Water retention. In: Methods of Soil Analysis, Part 1, Physical and Mineralogical Methods. Agronomy Monograph No. 9 (Ed.: Klute, A.). American Society of Agronomy and Soil Science Society of America, Madison, Wisconsin. pp.635-662.

Koelling, M.R., 1995. Soil and Christmas tree production soil $\mathrm{pH}$. Michigan Christimas. Tree J. 41(1), 37-41.

Landon, J.R., 1984. Tropical Soil Manual. Booker Tate Ltd. p. 475.

Landon, J. R., 1991. Booker Tropical Soil Manual. A handbook for soil survey and agricultural land evaluation in the tropics and subtropics. Longman Scientific and Technical Publishers, Essex. p. 474.

Lindsay, W.L. and Norvell, W.A., 1978. Development of DTPA soil test for zinc, iron, manganese and copper. Soil Sci. Soc. Amer. J. 42, 421- 428.

McLean, E. O., 1986. Soil pH and lime requirement. In: 
Methods of Soil Analysis, Part 2, Chemical and Mineralogical Properties (Eds.: Page, A.L., Miller, R. H., Keeny, D. R.). $2^{\text {nd }}$ Edn. Agronomy Monograph no. 9. American Society of Agronomy and Soil Science Society of America, Madison, Wisconsin. pp.199-223.

Massawe, I.H., Msanya, B.M., Rwehumbiza, F. B., 2017. Pedological characterization and fertility evaluation of paddy soils of Mvumi village, Kilosa District, Tanzania. Int. J. Curr. Res. Biosci. Plant Biol. 4(4), 49-60.

Ministry of Agriculture, Food and Cooperatives (MAFC), 2014. Expanding rice production project. Environmental and Social Management Frame Work, Tanzania.

Msanya, B.M., Kaaya, A.K., Araki, S., Otsuka, H., Nyadzi, G.I., 2003. Pedological characteristics, general fertility and classification of some benchmark soils of Morogoro District, Tanzania. Science and Engineering Series. Afr. J. Sci. Technol. 4(2), 101-112.

Msanya, B. M., Kimaro, D. N., Kileo, E. P., Kimbi, G. G., Munisi, A. I. M., 2001. Land Resources Inventory and Suitability Assessment for the Production of the Major Crops in the Eastern Part of Morogoro Rural District, Tanzania. Soils and Land Resources of Morogoro Rural and Urban Districts, Vol. 3. Department of Soil Science, Faculty of Agriculture, Sokoine University of Agriculture, Morogoro, Tanzania. 69p.

Msanya, B. M., Munishi, J. A., Amuri, N., Semu, E., Mhoro, L., Malley, Z., 2016. Morphology, genesis, physico-chemical properties, classification and potential of soils derived from volcanic parent materials in selected Districts of Mbeya Region, Tanzania. Int. J. Plant Soil Sci. 10(4), 1-19.

National Soil Service (NSS), 1990. Laboratory Procedures for Routine Analysis. Agricultural Research Institute, Mlingano, Tanga, Tanzania. 212p.
Nelson, D.W., Sommers, L.E., 1982. Total Organic Carbon. In: Methods of Soil Analysis, Part 2. Chemical and Microbiological Properties (Ed.: Page, A. L.). $2^{\text {nd }}$ Edn. American Society of Agronomy, Madison. pp.539-579.

Rhoades, J.D., 1996. Salinity: Electrical conductivity and total dissolved solids. In: Methods of Soil Analysis, Part 3: Chemical Methods (Ed.: Sparks, R.L.). Soil Science Society of America, Madison. pp.417-435.

Shio, K., 1996. Phosphorus. In: Methods of Soil Analysis, Part 3: Chemical Methods (Ed.: Sparks, R.L.). Soil Science Society of America, Madison. pp.864-920.

Soil Survey Staff, 2014. Keys to Soil Taxonomy. $12^{\text {th }}$ Edn. United States Department of Agriculture, Natural Resources Conservation Service.

Sumner, M.E., Miller, W.P., 1996. Cation exchange capacity. In: Methods of soil analysis. Part 3, Chemical Methods (Ed.: Sparks, R.L.). Soil Science Society of America, Madison. pp.475-490.

United States Department of Agriculture (USDA), 1975. Soil Taxonomy: A Basic System of Soil Classification for Making and Interpreting Soil Surveys. Soil Conservation Service, Washington DC. $754 \mathrm{p}$.

Uwingabire, S., Msanya, B.M., Mtakwa, P.W., Uwitonze, P., Sirikare, S., 2016. Pedological characterization of soils developed on gneissic granites in the Congo Nile Watershed Divide and Central Plateau Zones, Rwanda. Int. J. Curr. Res. 89(9), 39489-39501.

Uwitonze, P., Msanya, B. M., Mtakwa, P. W., Uwingabire, S., Sirikare, S., 2016. Pedological characterization of soils developed from volcanic parent materials of Northern Province of Rwanda. Agric. For. Fish. 5(6), 225-236.

Zonn, S.V., 1986. Tropical and Subtropical Soil Science. Mir Publishers, Moscow. 422p.

\section{How to cite this article:}

Mbaga, H. R., Msanya, B. M., Mrema, J. P., 2017. Pedological characterization of typical soil of Dakawa Irrigation Scheme, Mvomero District, Morogoro Region, Tanzania. Int. J. Curr. Res. Biosci. Plant Biol. 4(6), 77-86. doi: https://doi.org/10.20546/ijcrbp.2017.406.009 